\title{
Evaluation of the Adequacy of the Vidas $®$ SET2 Kit in the Detection of Staphylococcal Enterotoxins in Cheese of Portuguese Origin
}

\author{
Silva $\mathrm{E}^{1}$, Furtado $\mathrm{R}^{1}$, Bragança $\mathbf{M}^{2}$, Correia $\mathrm{CB}^{1}$, Pedroso $\mathrm{L}^{2}$, Santos MIS ${ }^{2,3 *}$ \\ ${ }^{1}$ Instituto Nacional de Saúde Doutor Ricardo Jorge, Portugal \\ ${ }^{2}$ Faculty of Veterinary Medicine, Universidade Lusófona de Humanidades e Tecnologias, Portugal \\ ${ }^{3}$ Disease \& Stress Biology, DRAT, LEAF, ISA, Universidade de Lisboa, Tapada da Ajuda, 1349-017 Lisbon, Portugal \\ Submission: January 16, 2018; Published: February 28, 2018 \\ *Corresponding author: Santos MIS, Faculty of Veterinary Medicine, Universidade Lusófona de Humanidades e Tecnologias, Portugal, \\ Email: missantos@gmail.com
}

\begin{abstract}
Under suitable conditions, S. aureus can produce enterotoxins in sufficient quantity to cause food poisoning.

The European official method for detection of staphylococcal enterotoxins (SEs) in cheese is the Vidas ${ }^{\circledR}$ SET2 kit, with prior concentration of toxins through dialysis membrane. To evaluate this method's adequacy and the effect of different food matrixes in test results, 30 samples of Portuguese cheese were sampled and examined.
\end{abstract}

Keywords: Staphylococcus aureus; Staphylococcal enterotoxins; Cheese; European official method

Abbreviations: SEs: Staphylococcal Enterotoxins; PTSAgs: Pyrogenic Toxin Superantigens; SEls: Staphylococcal Enterotoxin-like Toxins; EC: European Community

\section{Introduction}

Diseases transmitted through food are the most widespread health problem in the contemporary world [1-2].

Cheese is one of the most consumed dairy products. Its constitution and nature allows the rapid growth of microorganisms including $S$. aureus [3]. The main concern of food contamination with these bacteria relates to the fact that enterotoxigenic strains have the ability to produce SEs when in sufficient concentration [4].

Over the recent years the outbreak percentage of food poisoning caused by bacterial toxins have increased in Europe, with the SEs representing a major part of them [5]. These extracellular proteins are classified as Pyrogenic Toxin Superantigens (PTSAgs), since they have the capacity to induce $\mathrm{T}$ lymphocyte proliferation without depending on the antigen specificity [6-7].

Only PTSAgs with proven capacity to induce emetic response in primate models are considered SEs. Those who have not shown this capability, nor have yet been tested for this specific purpose, are designated Staphylococcal Enterotoxinlike Toxins (SEls). Whilst several staphylococcal toxins, with super antigenic activity, have been described, only few are able to trigger emetic response. The total repertoire comprises now 22 members, divided into classical SEs and new SEs, which also include SEls [8]. The SEs most commonly associated with food poisoning are SEA and SED [9].

In order to harmonize food control for milk products, the European Community issued the Regulation (EC) 2073/2005, subsequently amended by Regulation (EC) 1441/2007 which prescribes the detection of SEs in cheeses made from raw milk and heat-processed milk when the count of $S$. aureus is greater than $105 \mathrm{CFU} / \mathrm{g}$ in the production phase where the expected count is higher.

The implementation of European regulation requires that the detection of SEs in cheese is performed using the method indicated by the Reference Laboratory of the European Union for coagulase-positive staphylococci - ANSES. This method consists of using SEs detection kit Vidas $®$ SET2, performing an extra step of concentration of SEs through a dialysis membrane.

The present study aims to evaluate the adequacy of the Vidas ${ }^{\circledR}$ SET2 kit in SEs detection in cheese, taking into account the type of milk used in the cheese manufacture and the distinct ripening process to which they are submitted to. 


\section{Material and Methods}

A total of 30 cheese samples of Portuguese origin were tested, 15 being contaminated by inoculation and the other 15 not contaminated. The samples belonged to various manufacturers and brands, were produced with milk from different sources and submitted to different processing technologies (Table 1). One exception was a homemade cheese (produced under unknown conditions).

Table 1: Types of cheese analyzed, grouped according to the origin of the milk and maturation

\begin{tabular}{|c|c|c|c|c|c|}
\hline & \multicolumn{4}{|c|}{ Milk Origin } & \multirow{2}{*}{ Total } \\
\cline { 2 - 5 } & Goat & Mixture & Sheep & Cow & \\
\hline $\begin{array}{c}\text { Ripened } \\
\text { Cheese }\end{array}$ & 4 & 9 & 8 & 3 & 24 \\
\hline $\begin{array}{c}\text { Unripened } \\
\text { Cheese }\end{array}$ & 0 & 0 & 1 & 5 & 6 \\
\hline & 4 & 9 & 9 & 8 & 30 \\
\hline
\end{tabular}

The samples were randomly collected between September and December of 2011 in supermarkets of the district of Setúbal, Portugal, and transported to the laboratory still packed in its original form.

For processing purposes, individual cheese samples were taken accordingly to ISO 7218:2007, starting by mixing various parts of the cheese that would allow the sample to represent a whole, including $10 \%$ of the rind. For the inoculation process of these samples, five enterotoxigenic strains of $S$. aureus were used. One of these had lost its enterotoxic activity. The intensity of the bacteria multiplication was measured through the degree of turbidity according to McFarland's nephelometric scale, in order to obtain standardization of the inoculums.

For counts of S. aureus was used BP-RPF Agar (Baird Parker Rabbit Plasma Fibrinogen), according to ISO 6888-2:1999. After serial dilutions of the sample, taking into account ISO 6887 1:1999, the culture medium was inoculated by incorporation and incubated at $37^{\circ} \mathrm{C} \pm 1{ }^{\circ} \mathrm{C}$ for $24 \mathrm{~h}$ and $48 \mathrm{~h}$. The calculations used for the counting of CFU were performed according to ISO 7218:2007.

For enterotoxin detection was used Vidas $₫$ SET 2 kit, proper for the equipment miniVIDAS $®$. In the prior concentration step was used dialysis membrane SpectralPor ${ }^{\circledR}$.

The data were analyzed with PASW-SPSS ${ }^{\circledR}$ software and adopting a significance level of $5 \%$ in all statistical tests performed.

The results for SEs detection using the Vidas ${ }^{\circledR}$ SET2 kit were analyzed automatically by the Vidas ${ }^{\circledR}$ instrument. Two fluorescence measurements were performed for each test (sample and standard) resulting in two relative fluorescence values (RFV). The ratio between these two measurements is called test value (TV) and its interpretation declares a sample positive or negative for the presence of SEs. The sample is considered positive if the TV is equal or greater than 0.13 .

\section{Results and Discussion}

The mean value of TV for the negative result is 0.0119 (CI95\% [0.0000, 0.0246]) whilst the positive mean value is 0.6444 (CI95\% $[0.2649,1.0240])$ ), as shown in Table 2.

Table 2: Results of the statistical tests applied to the data, concerning TV and RFV.

\begin{tabular}{|c|c|c|c|c|c|c|}
\hline & Result & Mean & Median & Std. deviation & Minimum & Maximum \\
\hline \multirow{3}{*}{ RFV } & Negative & 66.71 & 25 & 108.64 & 10 & 445 \\
\cline { 2 - 8 } & Positive & 2594 & 2435 & 1963.03 & 17 & 5618 \\
\hline \multirow{2}{*}{ TV } & Negative & 0.0119 & 0 & 0.02786 & 0.00 & 0.11 \\
\cline { 2 - 8 } & Positive & 0.6444 & 0.6 & 0.49374 & 0.00 & 1.41 \\
\hline
\end{tabular}

As expected, the Mann-Whitney U test suggests that there are significant differences for the TV and RFV values between positive and negative classifications ( $p$-value $<0.001$ ).

The mean value of TV obtained for the samples of cheese made with a mixture of milks from different animals is 0.19933 (CI95\% [0.0000, 0.4648]) whilst the TV mean value for cheese made with milk from a single animal is 0.2052 (CI95\% [0.0151, 0.3953]). The TV mean values concerning the type of cheese analyzed are 0.1808 (CI95\% [0.0313, 0.3304]) for ripened cheese and 0.2850 (CI95\% [0.0000, 0.8691]) for fresh cheese. All statistical results, as for the statistical results for TV, are presented in Table 3.

Table 3: Statistical results for RFV and TV values according to the milk origin and cheese type.

\begin{tabular}{|c|c|c|c|c|c|c|c|}
\hline & & Mean & Median & Std. deviation & Minimum & Maximum & \\
\hline \multirow{4}{*}{ Milk Origin } & \multirow{2}{*}{ RFV } & Mixture & 794.67 & 50 & 1420.224 & 16 & 3313 \\
\hline & & Single animal & 837.86 & 25 & 1660.647 & 10 & 5618 \\
\hline & \multirow{2}{*}{$\mathrm{TV}$} & Mixture & 0.1933 & 0.01 & 0.35313 & 0 & 0.82 \\
\hline & & Single animal & 0.2052 & 0 & 0.41761 & 0 & 1.41 \\
\hline \multirow{4}{*}{ Cheese Type } & \multirow{2}{*}{$\mathrm{RFV}$} & Ripened & 744.71 & 37 & 1415.17 & 10 & 5146 \\
\hline & & Fresh & 1145.67 & 232.5 & 2212.199 & 10 & 5618 \\
\hline & \multirow{2}{*}{$\mathrm{TV}$} & Ripened & 0.1808 & 0 & 0.35419 & 0 & 1.29 \\
\hline & & Fresh & 0.285 & 0.055 & 0.55659 & 0 & 1.41 \\
\hline
\end{tabular}


When evaluating the relationship between the cheese ripening characteristics and the results of SEs detection, using the VIDAS SET2 kit with concentration through dialysis membrane, the results detailed in Table 4 were obtained. The Fisher's exact test suggests that there is no statistically significant relationship between the cheese ripening process and the result $(\mathrm{p}$-value $=0.329)$. The Mann-Whitney $\mathrm{U}$ test for independent samples suggests there are no statistically significant differences between RVF values among the two cheese types ( $p$-value $=0.940)$. According to expectations no significant differences were found for TV between ripened cheese and fresh cheese ( $p$-value=0.667).

Table 4: Results obtained for SEs detection using the VIDAS ${ }^{2}$ SET2 kit with concentration process according to the type of cheese analyzed.

\begin{tabular}{|c|c|c|c|c|}
\hline \multicolumn{2}{|c|}{ Cheese Type: } & Ripened & Unripened/Fresh & Total \\
\hline \multirow{2}{*}{ Result } & Negative & 18 & 3 & 21 \\
\cline { 2 - 6 } & Positive & 6 & 3 & 9 \\
\hline \multirow{2}{*}{ Total } & & 24 & 6 & 30 \\
\hline
\end{tabular}

Regarding the origin of the milk used in the cheese making process, being it a mixture of milks from different animals (cow, goat and sheep) or milk from just one animal, the Fisher's exact test suggests there is no significant dependence between the results obtained and the origin of the milk ( $\mathrm{p}$-value $=0.681)$. The results are presented in Table 5.

Table 5: Results obtained for SEs detection, using the VIDAS ${ }^{2}$ SET2 kit with concentration process, according to the type of milk.

\begin{tabular}{|c|c|c|c|c|}
\hline & & \multicolumn{2}{|c|}{ Milk Origin } & Total \\
\hline & & Mixture & $\begin{array}{c}\text { Single Animal (Cow, } \\
\text { Goat or Sheep) }\end{array}$ \\
\hline Result & Negative & 7 & 14 & 21 \\
\hline & Positive & 2 & 7 & 9 \\
\hline Total & & 9 & 21 & 30 \\
\hline
\end{tabular}

The Mann-Whitney U test for independent samples suggests that there are no statistically significant differences between RVF nor TV among the two possible types of cheese analyzed, regarding the origin of the milk used in its production ( $\mathrm{p}$-value $=0,263$ and $\mathrm{p}$-value $=0.476$, respectively) .

\section{Conclusion}

In conclusion, the Vidas $₫$ SET2 kit, coupled with concentration through membrane dialysis proved to be a very suitable method for SEs detection in different types of Portuguese cheese. Without any false-negative nor falsepositive results, all non-contaminated samples gave negative results, as expected, and all contaminated samples gave positive results, except the ones contaminated with the strain whose ability to produce enterotoxins had been lost.

No interference of the food matrix in the final test results was observed. Also, the animal origin of the milk used in the cheese production doesn't seem to interfere with the SEs detection.

\section{References}

1. Baird-Parker TC (2000) The Production of Microbiologically Safe and Stable Foods. In: Lund BM, et al., (Eds), The Microbiology Safety and Quality of Food, Aspen Publishers Inc., USA, p. 3-18.

2. World Health Organization (2012).

3. Gil Á (2010) Tratado de Nutrición - Composición y calidad nutritiva de los alimentos, $\left(2^{\text {nd }}\right.$ edn $)$, Medica Panamericana, Spain.

4. Bergdoll MS, Wong AL (2006) Staphylococcal Intoxications, Foodborne Infections and Intoxications, Elsevier Inc., Netherlands, pp. 523-552.

5. EFSA (2011) Trends and Sources of Zoonoses, Zoonotic Agents and Food-borne Outbreaks in 2009 9(3).

6. Dinges MM, Orwin PM, Schlievert PM (2000) Exotoxins of Staphylococcus aureus, Clinical Microbiology Reviews 13: 16-34.

7. Seo KS, Bohach GA (2007) Staphylococcus aureus. In: Doyle MP \& Beuchat LR (Eds.), Food microbiology fundamentals and frontiers, ASM Press, Washington, EUA,USA, pp. 493-513.

8. Argudín MÁ, Mendoza MC, Rodicio MR (2010) Food poisoning and Staphylococcus aureus enterotoxins. Toxins (Basel) 2(7): 1751-1773.

9. Lee YD, Moon BY, Park JH, Chang HI, Kim WJ (2007) Expression of enterotoxin genes in Staphylococcus aureus isolates based on mRNA analysis. J Microbiol Biotechnol 17(3): 461-467. 
This work is licensed under Creative Commons Attribution 4.0 License DOI: 10.19080/NFSIJ.2018.05.555669
Your next submission with Juniper Publishers will reach you the below assets

- Quality Editorial service

- Swift Peer Review

- Reprints availability

- E-prints Service

- Manuscript Podcast for convenient understanding

- Global attainment for your research

- Manuscript accessibility in different formats

( Pdf, E-pub, Full Text, Audio)

- Unceasing customer service

Track the below URL for one-step submission https://juniperpublishers.com/online-submission.php 